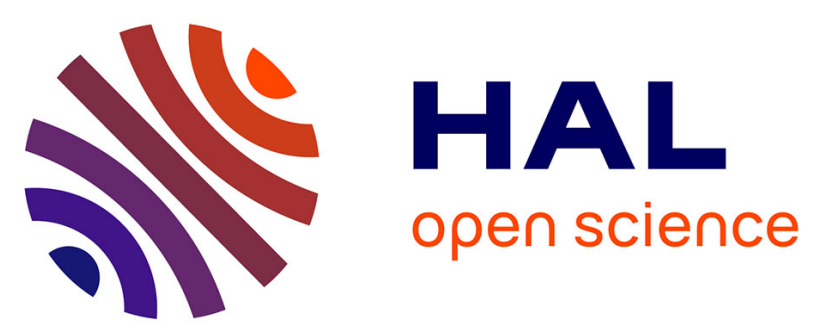

\title{
Two new species of Daidalotarsonemus (Acari: Prostigmata: Tarsonemidae) from Brazil
}

\author{
J.M. Rezende, A.C. Lofego, R. Ochoa
}

\section{To cite this version:}

J.M. Rezende, A.C. Lofego, R. Ochoa. Two new species of Daidalotarsonemus (Acari: Prostigmata: Tarsonemidae) from Brazil. Acarologia, 2015, 55 (4), pp.435-448. 10.1051/acarologia/20152183 . hal-01548615

\section{HAL Id: hal-01548615 https://hal.science/hal-01548615}

Submitted on 27 Jun 2017

HAL is a multi-disciplinary open access archive for the deposit and dissemination of scientific research documents, whether they are published or not. The documents may come from teaching and research institutions in France or abroad, or from public or private research centers.
L'archive ouverte pluridisciplinaire HAL, est destinée au dépôt et à la diffusion de documents scientifiques de niveau recherche, publiés ou non, émanant des établissements d'enseignement et de recherche français ou étrangers, des laboratoires publics ou privés.

\section{(ㅇ)(1) $\$$}

Distributed under a Creative Commons Attribution - NonCommercial - NoDerivatives $\mid 4.0$ 


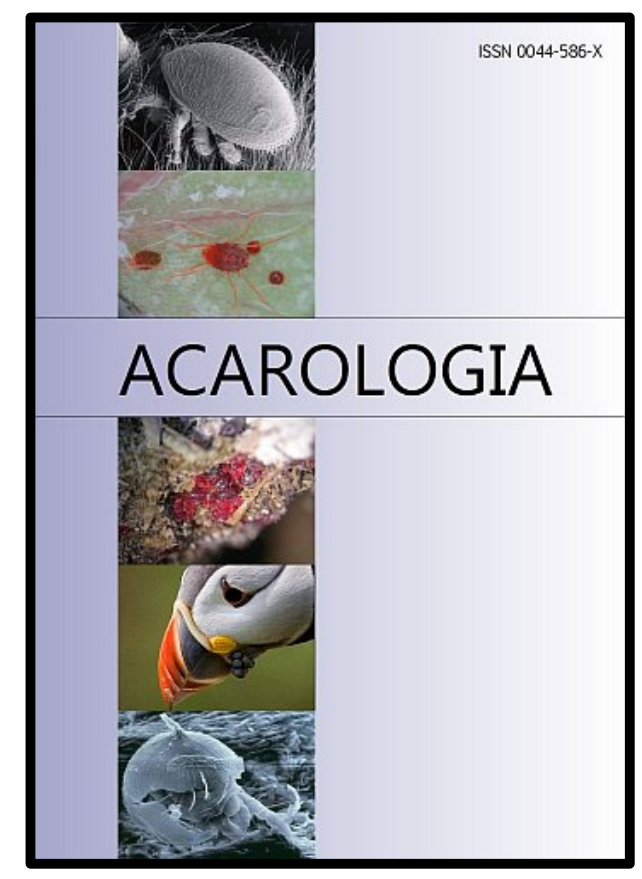

\section{ACAROLOGIA}

A quarterly journal of acarology, since 1959

Publishing on all aspects of the Acari

All information:

http://www1.montpellier.inra.fr/CBGP/acarologia/ acarologia@supagro.inra.fr

\section{OPEN ACCESS}

\section{Acarologia is proudly non-profit, with no page charges and free open access}

Please help us maintain this system by encouraging your institutes to subscribe to the print version of the journal and by sending us your high quality research on the Acari.

Subscriptions: Year 2017 (Volume 57): $380 €$ http://www1.montpellier.inra.fr/CBGP/acarologia/subscribe.php

Previous volumes (2010-2015): $250 € /$ year (4 issues)

Acarologia, CBGP, CS 30016, 34988 MONTFERRIER-sur-LEZ Cedex, France

The digitalization of Acarologia papers prior to 2000 was supported by Agropolis Fondation under the reference ID 1500-024 through the « Investissements d'avenir » programme

(Labex Agro: ANR-10-LABX-0001-01)
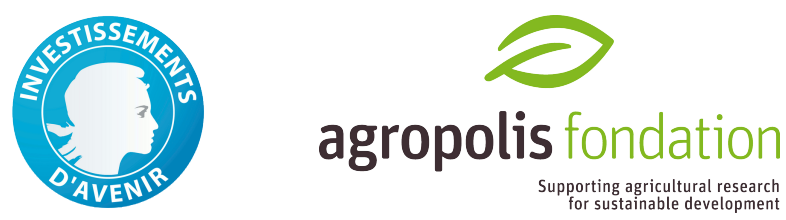

Acarologia is under free license and distributed under the terms of the

Creative Commons-BY-NC-ND which permits unrestricted non-commercial use, distribution, and reproduction in any medium, provided the original author and source are credited. 


\title{
Two new species of Daidalotarsonemus (Acari: Prostigmata: Tarsonemidae) from Brazil
}

\author{
José Marcos ReZENDE ${ }^{1 *}$, Antonio Carlos LOFEGO ${ }^{2}$ and Ronald OCHOA ${ }^{3}$ \\ (Received 13 August 2015; accepted 19 October 2015; published online 18 December 2015) \\ ${ }^{1}$ Programa de Pós-Graduação em Biologia Animal, Universidade Estadual Paulista, São José do Rio Preto, São Paulo 15054-000, Brazil. \\ jmrezende@live.com ( ${ }^{*}$ Corresponding author). \\ ${ }^{2}$ Departamento de Zoologia e Botânica, Universidade Estadual Paulista, São José do Rio Preto, São Paulo 15054-000, Brazil. aclofego@ig.com.br \\ ${ }^{3}$ Systematic Entomology Laboratory, United States Department of Agriculture, Agricultural Research Service, Beltsville, Maryland 20705, USA. \\ ron.ochoa@ars.usda.gov
}

\begin{abstract}
Two new tarsonemid species, Daidalotarsonemus esalqi n. sp. and Daidalotarsonemus savanicus n. sp., found on both native and crop plants in Brazil are described herein, based on adult females. Biological aspects of these species are briefly discussed. Individuals of Daidalotarsonemus savanicus $\mathbf{n}$. sp. have been misidentified as Daidalotarsonemus tessellatus De Leon in previous reports of this species from Brazil. A key is provided to distinguish females of the Daidalotarsonemus species known to occur in Brazil.
\end{abstract}

KEYWORDS - Heterostigmata; Cerrado; rubber tree; taxonomy

\section{INTRODUCTION}

The genus Daidalotarsonemus De Leon (1956) (Prostigmata: Tarsonemidae) currently consists of 37 described species. It has been registered on all continents, except Antarctica, and is considered a plant inhabiting group with apparent preference for humid places, with an abundance of algae, lichen and fungi (Lindquist 1986; Lin and Zhang 2002; Lofego et al. 2005; Sousa et al. 2014; Rezende et al. 2015a; b).

Three species, Daidalotarsonemus folisetae Lofego \& Ochoa, D. annonae Sousa, Lofego \& Gondim Jr. and D. oliveirai Rezende, Lofego \& Ochoa, have been described from Brazil (Lofego et al. 2005; Sousa et al. 2014; Rezende et al. 2015a). In addition, Daidalotarsonemus fossae De Leon was reported in the State of Pernambuco (Sousa et al. 2015). Based on an examination of specimens deposited in museum collections, two new Brazilian species of the genus, Daidalotarsonemus esalqi $\mathbf{n}$. sp. and Daidalotarsonemus savanicus n. sp., found in rubber tree crops and Cerrado sensu stricto habitats, respectively, are described and illustrated.

\section{MATERIALS AND METHODS}

Specimens were examined from the mite collections of Departamento de Entomologia, Fitopatologia e Zoologia Agrícola, Universidade de São Paulo, Escola Superior de Agricultura "Luiz de Queiroz" (ESALQ/USP), Piracicaba; and Departamento de Zoologia e Botânica (DZSJRP), Universidade Estadual Paulista, São José do Rio Preto, both from State 
of São Paulo, Brazil. They were analyzed by two techniques: phase contrast microscopy (PC) and differential interference contrast microscopy (DIC). The specimens were examined, drawn and photographed using an optical microscope Leica ${ }^{\circledR}$ DFC 500.

The terminology used herein mainly follows Lindquist (1986), except for gnathosomal setae $d g s$ and vgs (Magowski et al. 1998; Suski 1967). For each structure, the mean measurements are provided in micrometers $(\mu \mathrm{m})$, followed in parentheses by the range of the specimens measured (when available), including the holotype. For the diagnoses, comparisons with previously described species were based on the study of the types. The following abbreviations are used for institutions where the types are deposited: DZSJRP, ESALQ/USP and USNM (United States National Museum of Natural History, Smithsonian Institution, at National Insect and Mite Collection at USDA, SEL, Beltsville, Maryland, USA).

\section{RESULTS}

\section{Key to the species of Daidalotarsonemus from Brazil (based only on females)}

1. Setae $c 1$ inserted near posterior border of tergite $C$; tegula rounded apically $\ldots \ldots \ldots \ldots \ldots \ldots \ldots 2$ - Setae $c 1$ inserted in the middle of the tergite $C$ or near anterior border of this plate; tegula trun-

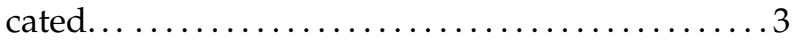

2. Posterior dorsal setae $d, e$ and $f$ leafshaped............... Daidalotarsonemus annonae Sousa, Lofego \& Gondim Jr.

- Posterior dorsal setae $d, e$ and $f$ rodshaped........... Daidalotarsonemus fossae De Leon

3. No rows of reticula on tergite $C \ldots \ldots \ldots \ldots \ldots$

- At least one row of reticula on tergite C......5

4. Setae $c 1$ setiform; setae $e$ phylliform................ Daidalotarsonemus folisetae Lofego \& Ochoa
- Setae $c 1$ with rounded tip; setae $e$ cordate..................Daidalotarsonemus oliveirai Rezende, Lofego \& Ochoa

5. Setae $e$ thin $( \pm 3 \mu \mathrm{m})$; palps long $( \pm 18$ $\mu \mathrm{m}) . . \ldots \ldots \ldots$....... Daidalotarsonemus esalqi $\mathbf{n}$. sp. (Figures 1-4)

- Setae $e$ broad $( \pm 17 \mu \mathrm{m}) ;$ palps short $( \pm 10$ $\mu \mathrm{m}) . . . \ldots \ldots$..... Daidalotarsonemus savanicus $\mathbf{n}$. $\mathbf{s p .}$ (Figures 5-8)

\section{Daidalotarsonemus esalqi $\mathbf{n} . \mathbf{s p}$. (Figures 1-4)}

Diagnosis - Females of this new species are most similar to Daidalotarsonemus venustus Attiah (1970) by the reticulated ornamentation on tergite $C$ and by the similar length of the dorsal setae $v 1, s c 2, c 1$, $c 2$ and $h$. However, they differ by having the ornamentation pattern on tergite $\mathrm{D}$ reticulated only between setae $d$ for $D$. esalqi; by the length of palps, longer for the new species; by pharynx shape, larger for D. esalqi; and by the shape, length and width of the posterior setae $d, e$ and $f$, all smaller for this new species.

Adult female (three specimens measured).

Gnathosoma - covered by the prodorsum, subtriangular in ventral view, length $34(32-36)$, maximum width 24 (23 - 26); dorsal apodeme distinct. Setae dgs $10(9-11)$ and vgs $7(7-8)$ smooth; palps long 17 (17 - 18), with one small subterminal seta. Pharynx fusiform, $14(13$ - 16) long and 8 (7 - 10) wide at maximum width.

Idiosoma - dorsum (Figures 1 and 4): length 201 (198 - 207), width at level of $c 197$ (95-102). Stigma located near lateral notch of prodorsal shield, which is equidistant to the $v 1$ and $s c 2$ setal bases. Prodorsum with regular ornamentation covering it; tergite $C$ with three transverse central rows of reticula and irregular ridges around it; tergite D with three central rows of reticula and irregular ridges around setae $d$. Lengths of the setae: $v 125(22-27)$, sc1 13 $(13-14)$, sc2 $27(24-30), c 118(16-21)$, c2 17 (16 $18), d 25(24-26)$, e $13(12-14), f 25(24-27)$ and $h$ $12(11-13)$. Maximum width of expanded setae: $d$ 


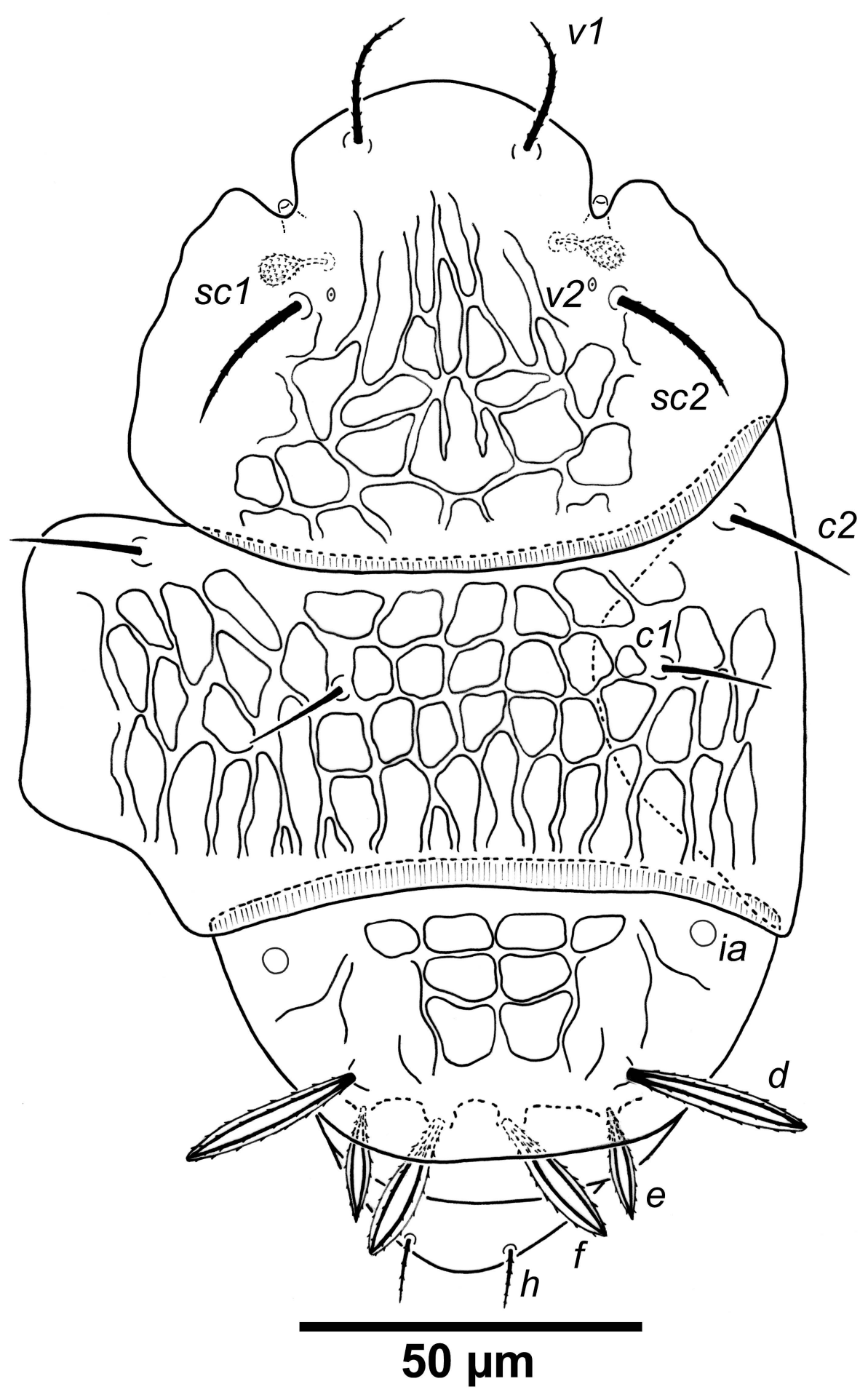

FIGURE 1: Daidalotarsonemus esalqi $\mathbf{n}$. sp. (female): Dorsal surface of the idiosoma. 
Rezende J.M. et al.

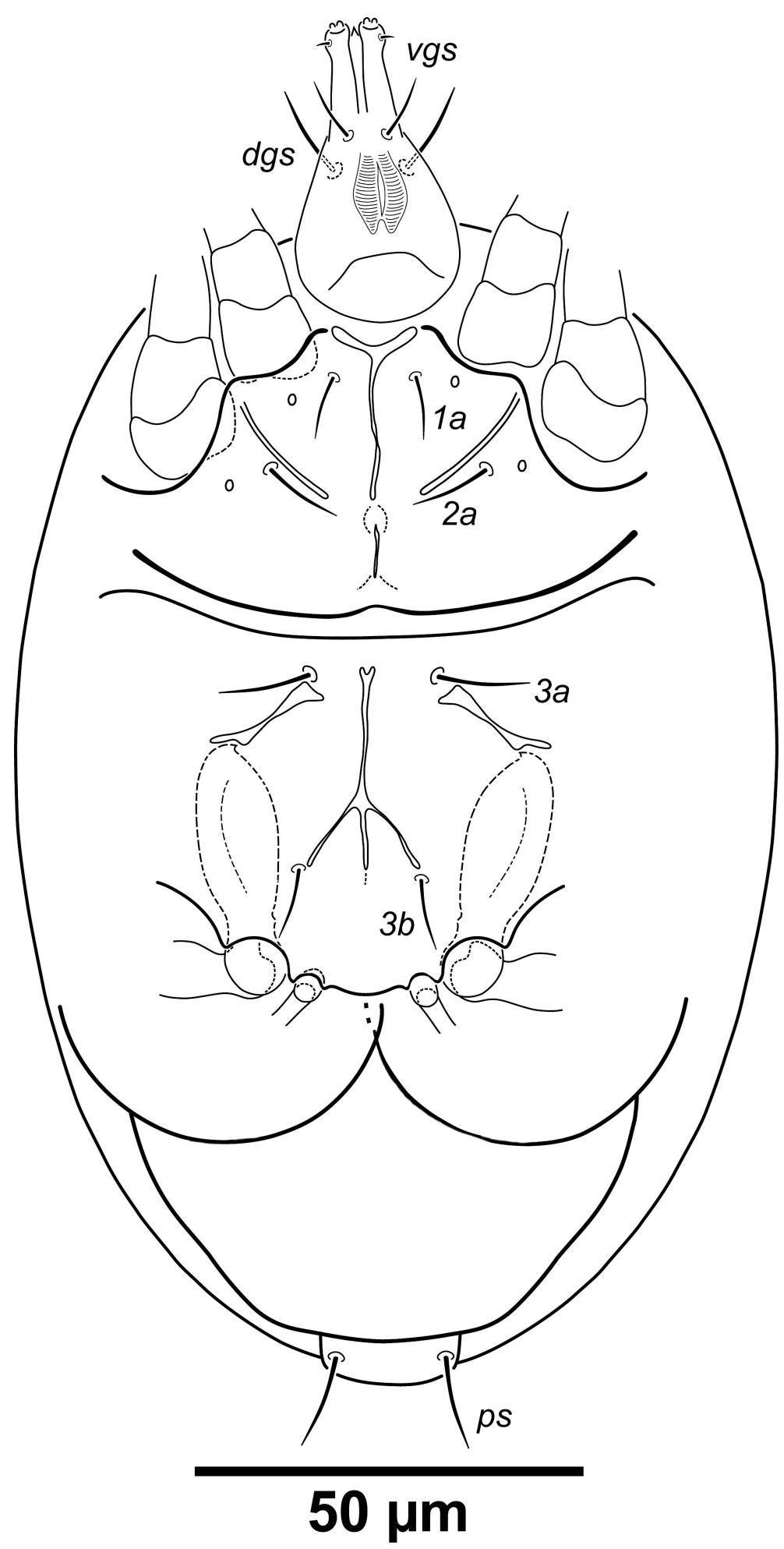

FIGURE 2: Daidalotarsonemus esalqi $\mathbf{n}$. sp. (female): Ventral surface of the idiosoma. 


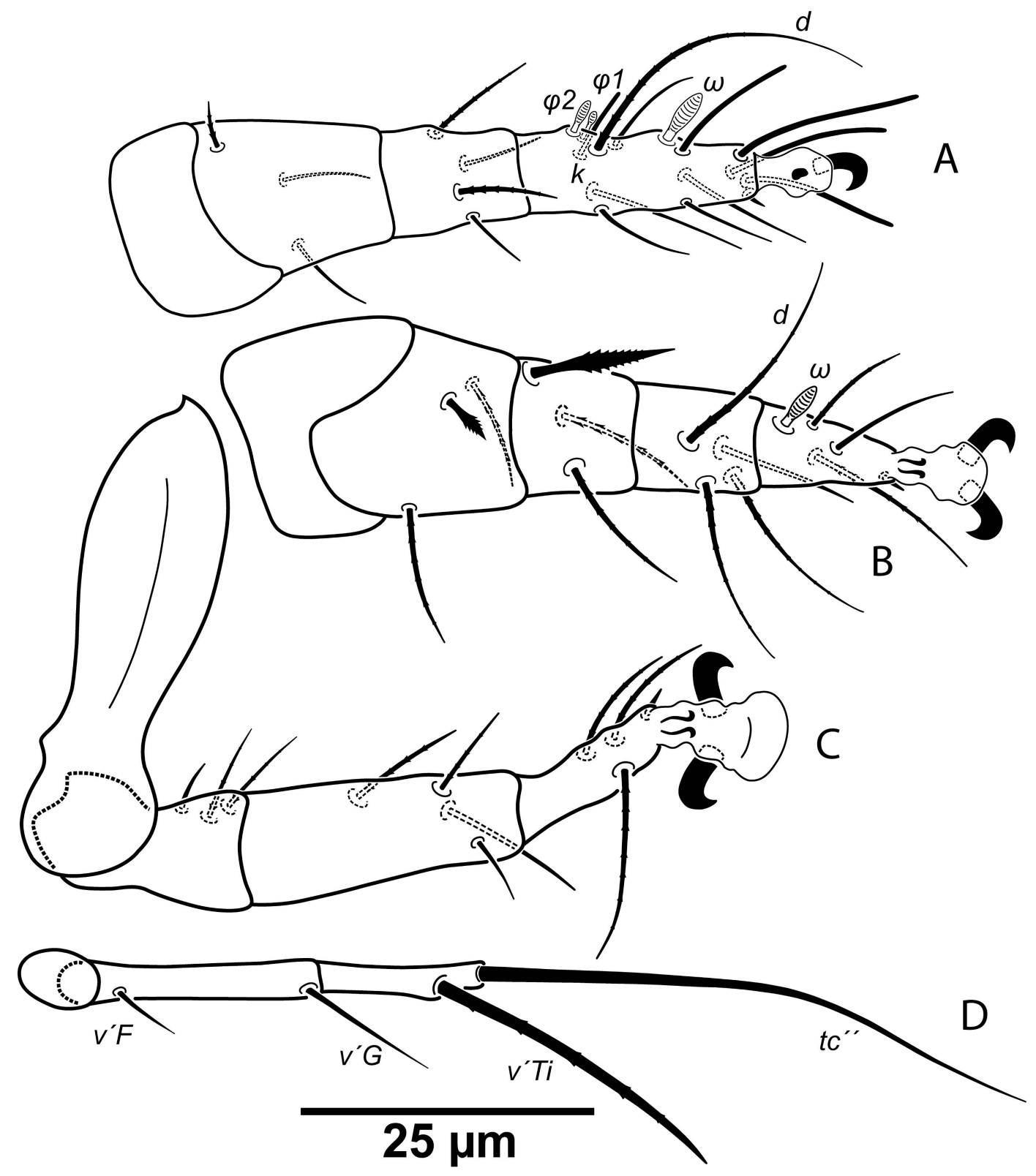

FIGURE 3: Daidalotarsonemus esalqi n. sp. (female). Legs: A - leg I; B - leg II; C - leg III; D - leg IV. 


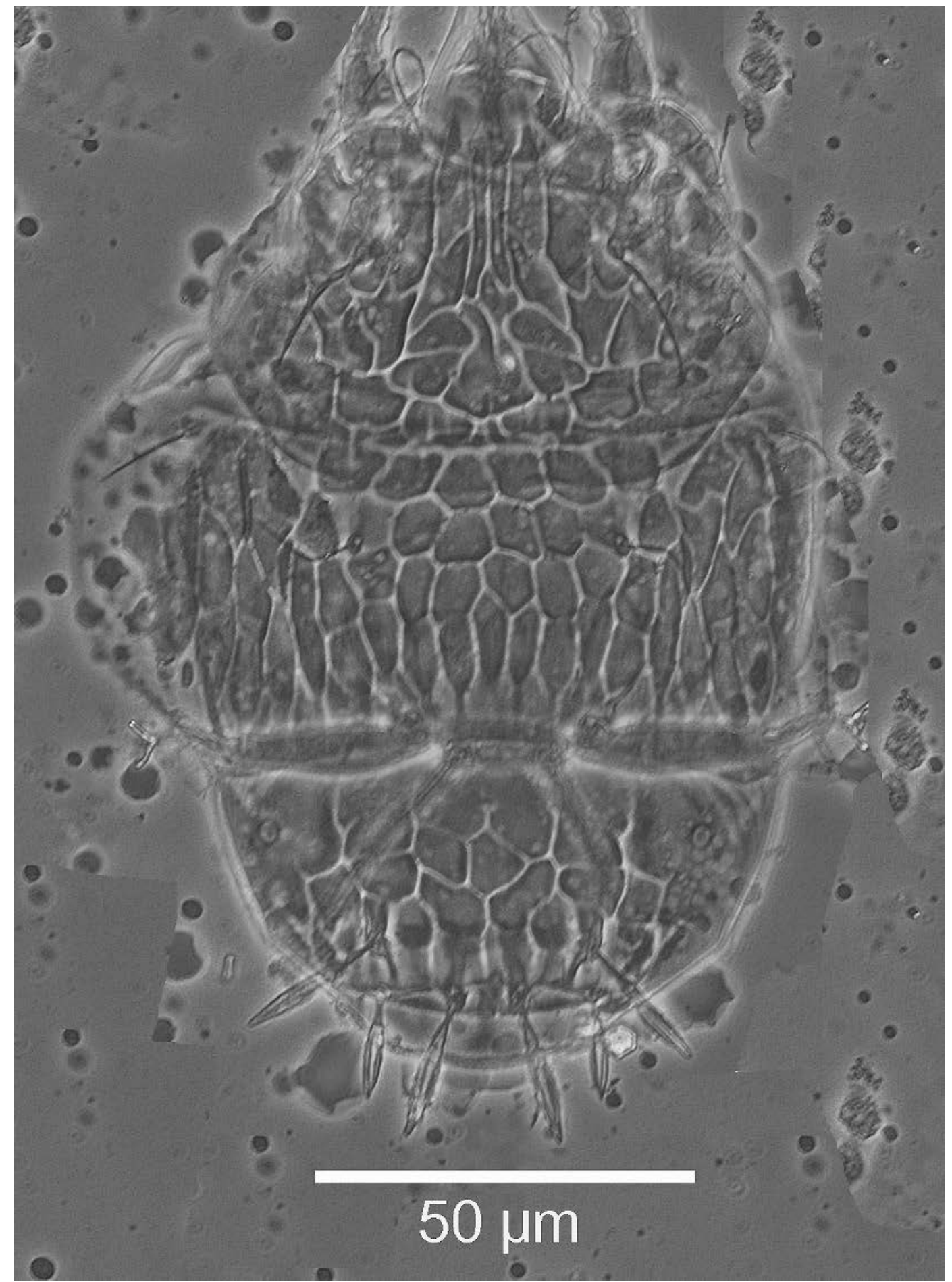

FIGURE 4: Daidalotarsonemus esalqi n. sp. (female): Dorsal micrograph of the idiosoma. 
$5, e 3$ and $f$ 7. All dorsal setae serrate; except for $c 1$ and $c 2$ smooth. Setae $v 1, c 1, c 2, d, e$ and $f$ inserted on tubercles. Setae $v 1, s c 2, c 1, c 2$ and $h$ setiform; setae $d, e$ and $f$ lanceolate with two central serrate veins. Distances between dorsal setae: v1-v1 28 (25 - 31), sc2-sc2 $45(42-48), v 1-s c 229(27-31), c 1-c 150$ (48 $52), c 2-c 297$ (94-101), c1-c2 $41(40-44), d-d 43$ (42 44), f-f $10(10-11)$, e-f $15(15-16)$ and $h$ - $h 16(14-$ 17). Seta $s c 2$ inserted posterolateral to $s c 1$.

Idiosoma - venter (Figure 2) - setae 1a 9 (9), posteriad of apodemes $1 ; 2 a 10(10-11)$, posterolaterad of apodeme 2; $3 a 13$ (12 - 15) near anteriomedial margins of apodemes $3 ; 3 b 11$ (10 - 12) on posterior margins of apodemes 4 . Apodeme 1 conspicuous, fused to anterior end of prosternal apodeme. Apodeme 2 long but not fused to prosternal apodeme. Prosternal apodeme conspicuous from junction with apodeme 1 to the proximal end of the apodeme 2, and diffuse from this point to the sejugal apodeme. Sejugal apodeme uninterrupted, with a median furrow. Apodeme 3 with a constriction near the anterior end, extending diagonally from proximity of base of seta $3 a$ to anterior margin of trochanter III; apodeme 4 extending diagonally from the middle of the poststernal apodeme to base of seta $3 b$. Poststernal apodeme bifurcated anteriorly. Tegula wide $25(23-26)$ and very short 5 (5); posterior margin slightly arched. Setae ps 15 (15 -16) serrate.

Legs (Figure 3) - lengths (femur to tarsus): leg I 57 (54 - 61), leg II 50 (48 - 52), leg III 84 (81 $88)$. Number of setae (solenidia in parentheses) on femur, genu, tibia and tarsus, respectively: leg I: 3-4-5(2)-7(1), leg II: 3-3-4-4(1), leg III: 3-4-4. Tarsal solenidion $\omega$ of tibiotarsus I 5 (5-6), stout, wider medially. Sensory cluster of tibia I complete, solenidion $\varphi 13(3-4)$, slender, capitate; solenidion $\varphi 23$ (3), robust, slightly capitate; famulus $k 5(5-6)$; all inserted at approximately the same level. Seta $d$ of tibia I $21(20-24)$, serrate. Solenidion $\omega$ of tarsus II proximal, 4 (4) long, stout, wider medially. Seta $d$ of tibia II $21(19-24)$, serrate. Femorogenu IV 16 (15-17); tibiotarsus IV 10 (9-11). Length of leg IV setae: $v^{\prime}$ F $6(6-7), v^{\prime}$ G $10(10-11)$, $v^{\prime}$ Ti 18 (17 20) and $t c^{\prime \prime} 45$ (45-46); all setae smooth, except for $v^{\prime}$ Ti serrate; $v^{\prime}$ Ti falcate.
Adult male and larva - Unknown.

Type material - Holotype and two paratypes. Holotype and paratypes from Hevea brasiliensis L. (Euphorbiaceae), $47^{\circ} 38^{\prime} \mathrm{W} 22^{\circ} 42^{\prime} \mathrm{S}$, Universidade de São Paulo, Escola Superior de Agricultura "Luiz de Queiroz" (ESALQ/USP), Piracicaba, State of São Paulo, 02/X/2002, R.M.J. De Vis. Holotype deposited at ESALQ/USP; and paratypes deposited at DZSJRP.

Etymology - the name esalqi is in honor of the university where this species was first registered. ESALQ is the acronym for Escola Superior de Agricultura "Luiz de Queiroz".

\section{Daidalotarsonemus savanicus n. sp. (Figures 5-8)}

Diagnosis - Females of this new species are most similar to Daidalotarsonemus tessellatus De Leon (1956) and Daidalotarsonemus ethiopicus Mahunka (1981) for the ornamentation pattern on tergite C and shape of anterior setae $v 1, s c 2, c 1$ and $c 2$. They differ from the others by the ornamentation pattern on tergite $\mathrm{D}$, with reticulation all over it including a rhomboid reticulum on the center of the plate; shape of posterior setae $d, e, f$ and $h$; and shape of the setae $p l$ " on tarsus II, which are stout and serrate.

Adult female (eight specimens measured).

Gnathosoma - covered by the prodorsum, subtriangular in ventral view, length $31(30-33)$, maximum width 20 (19-23); dorsal apodeme distinct. Setae $d g s 13(11-14)$ and vgs $9(8-10)$ smooth; palps short $9(9-10)$, with one small subterminal seta. Pharynx fusiform, 17 (15 - 18) long and wide10 (9 -12) at maximum width.

Idiosoma - dorsum (Figures 5 and 8) - length 228 (223 - 232), width at level of c1 141 (138 - 142); prodorsal shield with regular ornamentation. Stigma located near lateral notch of prodorsal shield, which is equidistant to the $v 1$ and $s c 2$ setal bases. Tergite $\mathrm{C}$ with four transverse central rows of reticula and irregular ornamentation laterally. Tergite $\mathrm{D}$ with irregular ridges, including a rhomboid reticulum on the center of the plate. Lengths of the setae: v1 $27(26-29)$, sc1 $12(11-14)$, sc2 38 (36- 


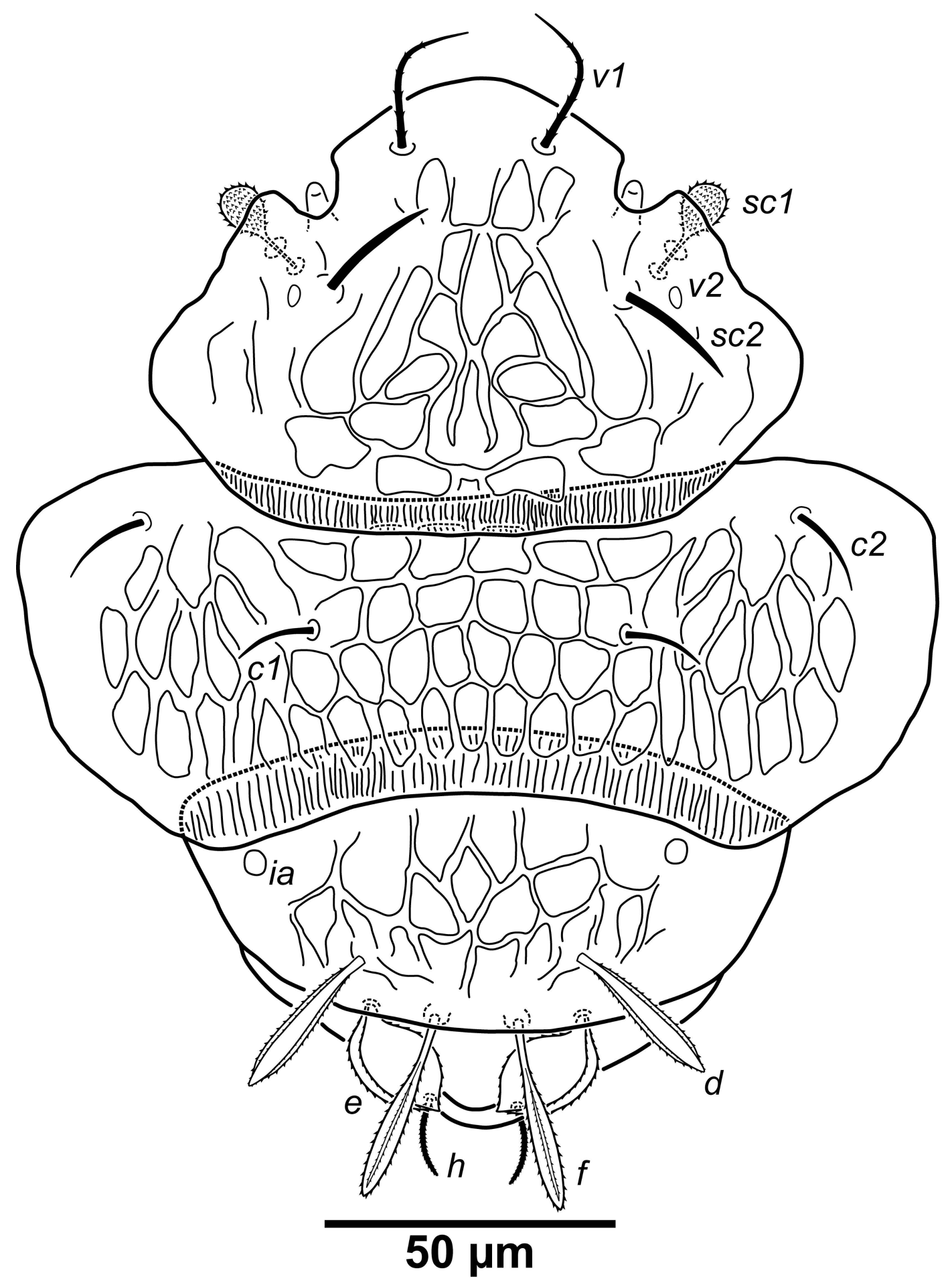

FIGURE 5: Daidalotarsonemus savanicus n. sp. (female): Dorsal surface of the idiosoma. 


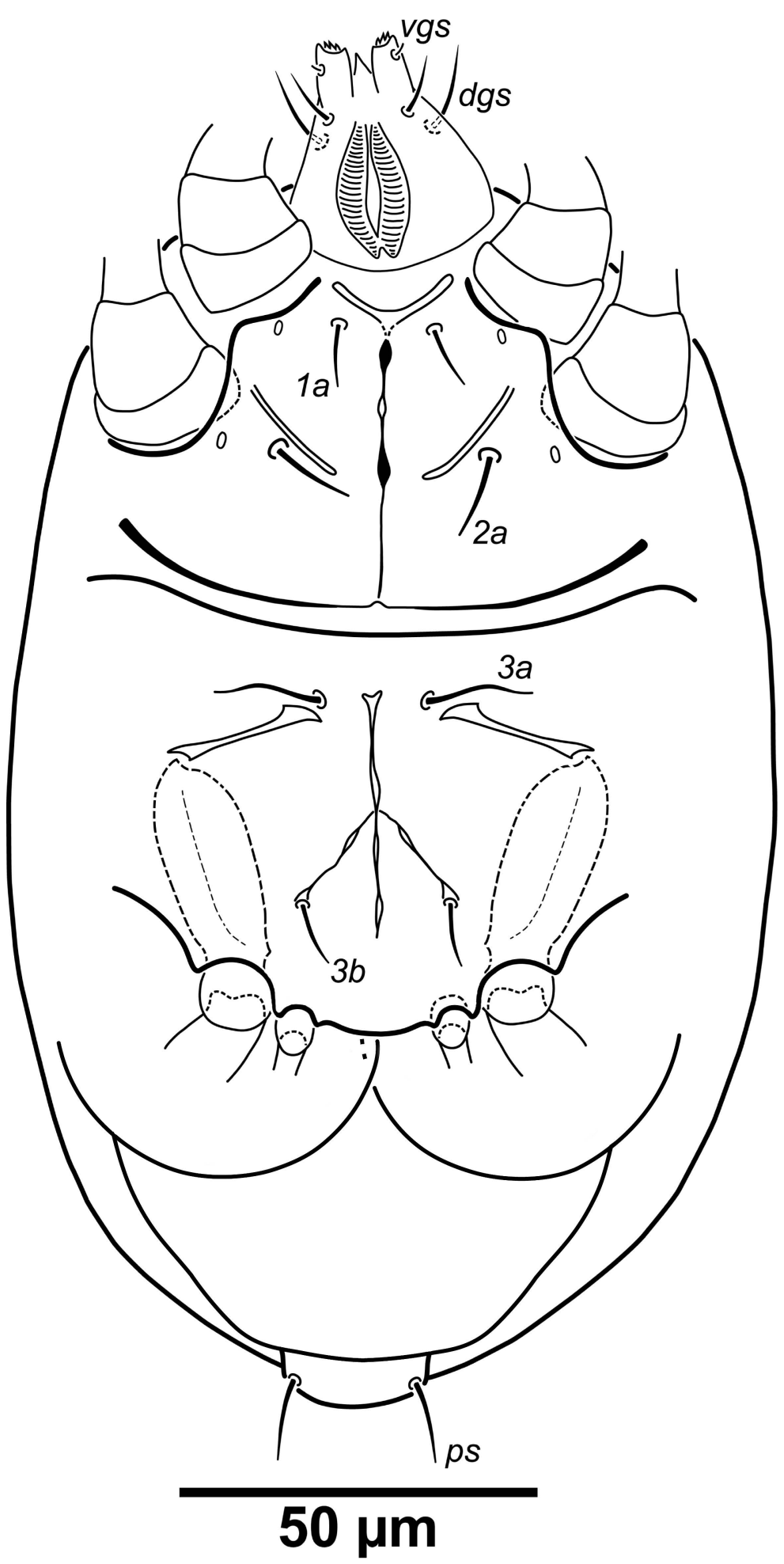

FIGURE 6: Daidalotarsonemus savanicus n. sp. (female): Ventral surface of the idiosoma. 
Rezende J.M. et al.

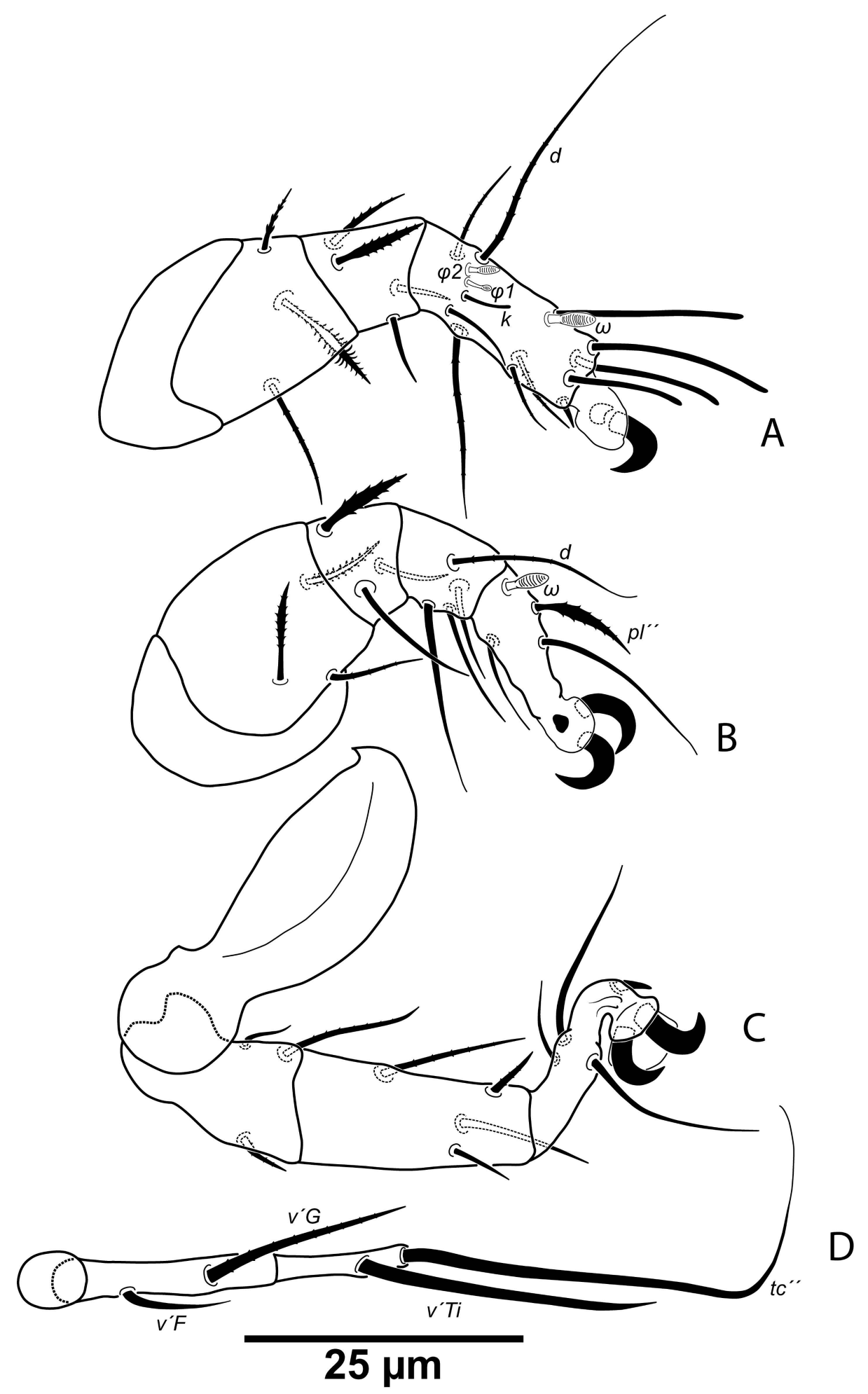

FIGURE 7: Daidalotarsonemus savanicus n. sp. (female). Legs: A - leg I; B - leg II; C - leg III; D - leg IV. 


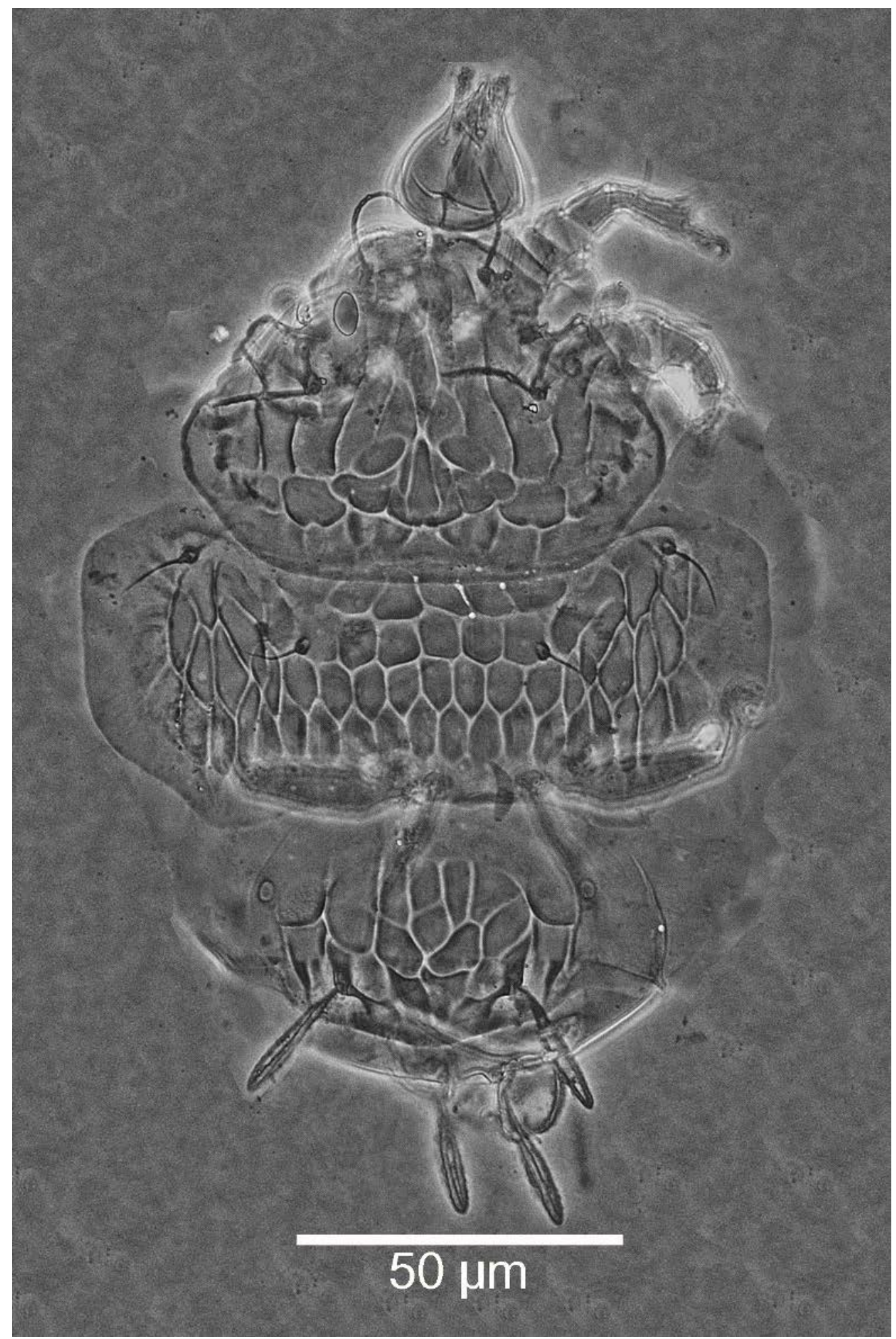

FIGURE 8: Daidalotarsonemus savanicus n. sp. (female): Dorsal micrograph of the idiosoma. 
40), c1 $18(16-20), c 217(15-18)$, d 34 (33 - 36), e 24 $(22-26), f 39(37-40)$ and $h 23(22-25)$. Maximum width of expanded setae: $d 7, e 17(16-18)$ and $f$ 6. All dorsal setae serrate; except for $s c 2, c 1$ and $c 2$ smooth. Setae $v 1, c 1, c 2$ and $h$ setiform; sc2 falcate; $d$ and $f$ lanceolate with two veins; $e$ asymmetrical, subelliptical, with one lateral vein. Distances between dorsal setae: v1-v1 $28(26-29), s c 2-s c 253(50$ - 54), v1-sc2 $30(29-31), c 1-c 156(54-57), c 2-c 2116$ $(115-117), c 1-c 237(36-39), d-d 38(37-40), f-f 14$ $(13-16)$, e-f $14(12-15)$ and $h-h 18(17-20)$. Setae $s c 2$ inserted posteromedial to sc1.

Idiosoma - venter (Figure 6) - setae 1a 7 (6 9), posteriad of apodemes $1 ; 2 a 9(8-9)$, posterolaterad and near middle of apodemes 2 ; $3 a 16$ (15 18) near anteriomedial margins of apodemes $3 ; 3 b$ 15 (13 - 17) on posterior margins of apodemes 4 . Apodeme 1 conspicuous, fused to anterior end of prosternal apodeme. Apodeme 2 not fused to the prosternal apodeme. Prosternal apodeme conspicuous from junction with apodeme 1 to the middle portion of sejugal apodeme, where is fused with it. Sejugal apodeme uninterrupted, with a median furrow. Apodeme 3 with a constriction near its middle, extending diagonally from proximity of base of seta $3 a$ to anterior margin of trochanter 3; apodeme 4 extending diagonally from the middle of the poststernal apodeme to base of seta $3 b$. Poststernal apodeme bifurcated anteriorly. Tegula 14 (12 - 15) wide and very short $4(4-5)$; posterior margin slightly arched. Setae ps $21(19-22)$ serrate.

Legs (Figure 7) - lengths (measured from femur to tarsus): leg I 45 (42 - 46), leg II 47 (45 - 48), leg III $85(83-86)$. Number of setae (solenidia in parentheses) on femur, genu, tibia and tarsus, respectively: leg I: 3-4-5(2)+7(1), leg II: 3-4-4-3(1), leg III: 3-4-4. Tarsal solenidion $\omega$ of tibiotarsus I 6 , stout, wider medially. Sensory cluster of tibia I complete, solenidion $\varphi 13$, slender, capitate; solenidion $\varphi 22$ (2-3), robust, slightly capitate; famulus $k 4(4-5)$; all inserted at approximately the same level. Seta $d$ of tibia I $13(12-15)$, serrate. Solenidion $\omega$ of tarsus II proximally inserted, 5 long, stout, wider medially; seta $p l^{\prime \prime}$ of tarsus II stout and serrate. Seta $d$ of tibia II 12 (11 - 14), serrate. Femorogenu IV 33 (31 - 34); tibiotarsus IV 9 (9). Length of leg IV setae: $v^{\prime}$ F 8 (7
-9), $v^{\prime} \mathrm{G} 17(16-19), v^{\prime} \mathrm{Ti} 25(23-26)$ and $t c^{\prime \prime} 59$ (58 - 62); all setae smooth, except for $v^{\prime} \mathrm{G}$ serrate; $v^{\prime} \mathrm{Ti}$ falcate.

Adult male and larva - Unknown.

Type material - Holotype and eleven paratypes. Holotype from Caryocar brasiliense Camb. (Caryocaraceae). Among paratypes, two from Campomanesia pubescens (DC.) Berg (Myrtaceae), one from Miconia albicans (Sw.) Triana (Melastomataceae), one from Myrtaceae sp., one from Pouteria torta (Mart.) Radlk. (Sapotaceae), $52^{\circ} 35^{\prime} \mathrm{W} 18^{\circ} 51^{\prime} \mathrm{S}$, Chapadão do Sul, State of Mato Grosso do Sul, 26/I/2010, J.M. Rezende, A.C. Lofego \& P.M. Paulon; one from Bauhinia sp. (Fabaceae), one from Didymopanax vinosum Cham. \& Schltdl. (Araliaceae), one from Myrtaceae sp., $52^{\circ} 44^{\prime} \mathrm{W} 18^{\circ} 15^{\prime} \mathrm{S}$, Chapadão do Céu, State of Goiás, 02/II/2010; one from Genipa americana L. (Rubiaceae), $51^{\circ} 45^{\prime} \mathrm{W} 17^{\circ} 51^{\prime} \mathrm{S}$, Jataí, State of Goiás, 05/II/2010; one from Xylopia aromatica (Lam.) Mart. (Annonaceae), 48 $54^{\prime} \mathrm{W} 18^{\circ} 31^{\prime} \mathrm{S}$, Tupaciguara, State of Minas Gerais, 10/II/2010; one from Caryocar

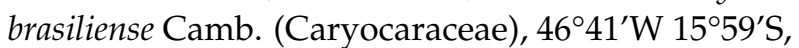
Unaí, State of Minas Gerais, 03/III/2010. Holotype and five paratypes deposited at DZSJRP; three paratypes deposited at ESALQ/USP; three paratypes deposited at USNM.

Etymology - the name savanicus refers to the Cerrado, a savannah biome in which this species is commonly found.

Remarks - Following an examination of voucher specimens, we conclude that individuals of this new species have been recorded as Daidalotarsonemus tessellatus De Leon in previous papers (Buosi et al. 2006, Demite et al. 2009, Feres et al. 2005, Lofego et al. 2005 and Sousa et al. 2015). The observations made by Lofego et al. (2005) regarding the habits for Daidalotarsonemus tessellatus, for which phytophagy was observed, should be conferred to Daidalotarsonemus savanicus.

\section{DISCUSSION}

Although Daidalotarsonemus has almost always been found in sites having a humid environment, the record of $D$. savanicus in the Cerrado reinforces 
that this genus is not exclusively from such places. The Cerrado biome is very dry weather for at least half of the year (Ribeiro and Walter 1998). Another species, Daidalotarsonemus ethiopicus Mahunka (1981), is also described from a region with similar dry conditions. Such a range of distribution may represent an extraordinary adaptation of this genus to different levels of humidity, which partially explains the worldwide distribution of the taxon. Also, the diversity of host plants for D. savanicus suggests that there is not a host preference for this species; instead, environmental factors might be more important for its occurrence in the Cerrado biome.

The finding of a new species inhabiting rubber trees, a well studied crop around the world, , demonstrates how poor our knowledge of the mite fauna of many areas remains. A large number of mite species have already been recorded in association with Hevea brasiliensis in Brazil (Hernandes and Feres 2006; Demite and Feres 2007; Bellini et al. 2008; Daud and Feres 2013; Nuvoloni et al. 2014; 2015). The added record of $D$. esalq $i$ highlights the importance for a better understanding of host plant inhabiting tarsonemid associations, and their ecological role in natural environments and cultivated areas.

\section{ACKNOWLEDGEMENTS}

To FAPESP (Fundação de Amparo à Pesquisa do Estado de São Paulo) (Procs. 2011/19890-0 and 2013/08402-0) for the financial support. To Dr. Gilberto J. de Moraes (ESALQ/USP) for providing the specimens of $D$. esalqi for study. To Chris Pooley (ECMU-USDA) for his help with the micrographs. To the Smithsonian Natural History Museum (USNM), National Agricultural Library (NAL-USDA), and the Systematic Entomology Laboratory (SEL-USDA), for the support and assistance with references for this study. To Dr. Gregory Evans (APHIS-USDA) for the review and the comments. Mention of trade names or commercial products in this publication is solely for the purpose of providing specific information and does not imply recommendation or endorsement by the USDA; USDA is an equal opportunity provider and employer.

\section{REFERENCES}

Attiah H. 1970 - New tarsonemid mites associated with citrus in Florida (Acarina: Tarsonemidae) - Fla. Entomol., 53: 179-201. doi:10.2307/3493188

Bellini M.R., Feres R.J.F., Buosi R. 2008 - Ácaros (Acari) de seringueira (Hevea brasiliensis Muell. Arg., Euphorbiaceae) e de euforbiáceas espontâneas no interior dos cultivos - Neotrop. Entomol., 37: 463-471. doi:10.1590/S1519-566X2008000400016

Buosi R., Feres R.J.F., Oliveira A.R., Lofego A.C., Hernandes F.A. 2006 - Ácaros plantícolas da "Estação Ecológica de Paulo de Faria", Estado de São Paulo, Brasil - Biota Neotrop., 6: 1-20. doi:10.1590/S167606032006000100009

Daud R.D., Feres R.J.F. 2013 - Community structure of mites (Arachnida: Acari) in six rubber tree clones. Int. J. Acarol., 39: 589-596. doi:10.1080/01647954.2013.856470

De Leon D. 1956 - Some mites from Lychee: Descriptions of two new genera and five new species of Tarsonemidae - Fla. Entomol., 39: 163-174. doi: $10.2307 / 3492593$

Demite P.R., Feres R.J.F. 2007 — Ocorrência e flutuação populacional de ácaros associados à seringais vizinhos de fragmentos de Cerrado - Neotrop. Entomol., 36: 117-127. doi:10.1590/S1519-566X2007000100015

Demite P.R., Feres R.J.F. Lofego A.C., Oliveira A.R. 2009 - Plant inhabiting mites (Acari) from the Cerrado biome of Mato Grosso State, Brazil - Zootaxa, 2061: 45-60.

Feres R.J.F. Lofego A.C., Oliveira A.R. 2005 Ácaros plantícolas (Acari) da "Estação Ecológica do Noroeste Paulista", Estado de São Paulo, Brasil - Biota Neotrop., 5: 1-14. doi:10.1590/S167606032005000100005

Hernandes F.A., Feres R.J.F. 2006 - Review about mites (Acari) of rubber trees (Hevea spp., Euphorbiaceae) in Brazil — Biota Neotrop., 6: 1-24. doi:10.1590/S167606032006000100005

Lin J., Zhang Z.Q. 2002 - Tarsonemidae of the world: Key to genera, geographical distribution, systematic catalogue \& annotated bibliography — London: Systematic and Applied Acarology Society. pp. 440.

Lindquist E.E. 1986 — The world genera of Tarsonemidae (Acari: Heterostigmata): a morphological, phylogenetic and systematic revision, with classification of family-group taxa in the Heterostigmata - Ottawa: Memoir 136, Entomological Society of Canada. pp. 517.

Lofego A.C., Ochoa R., Moraes G.J. 2005 — Some tarsonemid mites (Acari: Tarsonemidae) from the Brazilian 
"Cerrado" vegetation, with descriptions of three new species - Zootaxa, 823: 1-27.

Magowski W., Di Palma A., Khaustov A.A. $1998-U n-$ unguitarsonemus rarus (Acari Tarsonemidae) a new species of mite associated with bark beetle from Crimea, Ukraine - Entomologica (Bari), 32: 139-151.

Mahunka S. 1981 - Tarsonemiden aus Athiopien (Acari: Tarsonemina) — Folia Entomol. Hung., 42: 101-121.

Nuvoloni F.M., Lofego A.C., Rezende J.M., Feres R.J.F. 2014 - Phytoseiidae mites associated with Hevea spp. from the Amazon region: a hidden diversity under the canopy of native trees - Syst. Biodiv., 13: 182-206.

Nuvoloni F.M., Lofego A.C., Castro E., Feres R.J.F. 2015 Phytoseiidae (Acari: Mesostigmata) from rubber tree crops in the State of Bahia, Brazil, with description of two new species - Zootaxa, 3964: 260-274.

Rezende J.M., Lofego A.C., Ochoa R., Bauchan G. 2015a - New species of Daidalotarsonemus and Excelsotarsonemus (Acari, Tarsonemidae) from the Brazilian rainforest - Zookeys, 475: 1-36.

Rezende J.M, Ochoa R., Lofego A.C. 2015b - Ten new species of Daidalotarsonemus (Prostigmata: Tarsonemidae) from Costa Rica - Int. J. Acarol., 41: 449-493. doi:10.1080/01647954.2015.1080929
Ribeiro J.F., Walter B.M.T. 1998 - Fitofisionomias do bioma Cerrado - In: Sano M.S., Almeida S.P. (Eds). Cerrado: ambiente e flora. Brasília: Embrapa, p. 89106.

Sousa J., Lofego A.C., Gondim Jr. M.G.C. 2014 - Two new species of tarsonemid mites (Acari: Tarsonemidae) from northeastern Brazil - Zootaxa, 3889: 429441.

Sousa J.M., Gondim Jr. M.G.C., Lofego A.C., Moraes G.J. 2015 - Mites on Annonaceae species in northeast Brazil and in the state of Pará - Acarologia, 55: 5-18.

Suski Z. 1967 - Badania nad roztoczami z rodziny Tarsonemidae (Acarina, Heterostigmata) występującymi na jabłoniach w Polsce - Skierniewice: Institute of Pomology and Floriculture, pp. 268.

\section{COPYRIGHT}

$(\mathrm{cc})$ EY-No-ND Rezende J.M. et al. Acarologia is under free license. This open-access article is distributed under the terms of the Creative Commons-BY-NC-ND which permits unrestricted non-commercial use, distribution, and reproduction in any medium, provided the original author and source are credited. 